\title{
LINKING LEARNING CAPACITY AND BUSINESS PERFORMANCE: A RESEARCH AND EMPIRICAL ASSESSMENT
}

\section{IE Working Paper}

Isabel $\mathrm{M}^{\mathrm{a}}$ Prieto

Universidad de Valladolid

Spain

isabo@eco.uva.es
DO8-127-I

14-03-2005

Elena Revilla

Instituto de Empresa Operations and Tech. Management Dep. María de Molina 12, $5^{\mathrm{a}}$ planta 28006 Madrid, Spain

elena.revilla@ie.edu

\begin{abstract}
There has been little research that includes reliable deductions about the influence of knowledge and its associ ated learning processes on business performance. For this reason, the $\mathrm{m}$ ain objective of the present study is to empirically explore the link between learning flows in organizations, resulting knowledge stocks, and business perform ance evaluated in both financial and non-financial term s. Using data from 111 com panies, we conduct our research through a struct ural equation modeling. In doing so, we establish a measurement model for the main constructs and examine the paths between them. Results show the positive link existing between: (i) learning flows and knowledge stocks; (ii) knowledge stocks and nonfinancial performance; and (iii) non- financial performance and financial performance.
\end{abstract}

\section{Keywords}

Learning capacity, Performance, Knowledge Management 



\section{INTRODUCTION}

Today, there is no doubt in rec ognising knowledge as one of the $\mathrm{m}$ ost strategic weapons that can lead to achieving com petitive success (Grant, 1996; Spender, 1996). Hence, the ability to create knowledge, quickly share it, and apply it wh ere, how and when necessary is one of the most critical business com petencies to confront environm ental requirements (Nonaka and Takeuchi, 1995; Grant, 1996; Nonaka and Toyam a, 2003). This ability to adapt and leverage knowledge within organizations is the result of learning processes (Vera and Crossan, 2003), which involve the flowing of knowledge thr oughout the organization. Research has often described the organizational potential to lear $\mathrm{n}$ using this link between knowledge and its associated learning processes (Dierickx and Cool, 1989; Decarolis and Deeds, 1999; Bontis et al., 2002). This potential determines the organizational capability to learn.

Taking a theoretical or practical approach a growing body of literature has long acknowledged the importance of knowledge and learning pro cesses to overall business perform ance. The knowledge-based view of the firm argues that heterogeneous knowledge bases and capabilities among firms are the main determinants of performance differences (Grant, 1996; Decarolis and Deeds, 1999; Bontis et al., 2002), so firm s must exist to create, share and capitalise knowledge. Theoretical progress has also been $\mathrm{m}$ ade from the knowledge $\mathrm{m}$ anagement literature in identifying the direct link between knowledge $m$ anagement and business performance (Choi and Lee, 2003; Cecez-Kecmanovic, 2004; Chuang, 2004). Past studies have also tried to determine the link between organizational learning and business performance (Cangelosi and Dill, 1965; Slater and Narver, 1995; Calantone et al., 2002; Ellinger et al., 2002).

However, we think the analysis of the ef fects of a learning capability -in term $\mathrm{s}$ of both knowledge and its related learning processes- on bus iness performance is one of the most stirring to carry out positive contributions to this field for two reasons. First, there is no general consensus on how to def ine and operationalize the learning capability construct. Most researchers have viewed it as a single dimension, and it is also difficult to find reliable measures for this topic. Few empirical studies have system atically analyzed the measurement properties of this construct. Second, the relationship between learning processes, knowledge and business perform ance remains unclear. Empirical work about this topic is still limited and conclusions are unsatisfactory or even contradictory (Crossa $\mathrm{n}$ et al., 1995; Castaneda, 2000; Ellinger et al., 2002; Vera and Crossan, 2003).

The present study creates insight into the re lationship between the learning capability of organizations and business performance. For this exploration, a construct of learning capability is developed. Both knowledge and learning processes are identified as components of the learning capability. Learning capability is also proposed to be an im portant antecedent of business performance, which is valuated in financial and non-financial terms. In particular, we develop a conceptual model, drawn on organizational learni ng research, to explore how learning processes enacts knowledge in organizations, and how it can lead to improvements in business performance. In the next section, the conceptual fram ework is presented, and a set of testable hypothesis is proposed. Methods of study are then introduced, which includes information about the sam ple, measures, data analysis and results. Follo wing a discussion of results, lim itations, and implications for future research are offered. 


\section{THEORETICAL FRAMEWORK AND HYPOTHESIS}

The framework in Figure 1 was derived from literature on organizational learning, knowledge in organizations and intellectual cap ital (Bontis et al., 2002; Calantone et al., 2002; Choo and Bontis, 2003). Based on the literature, the learning capability is associated to two dimensions: the knowledge stocks and the learning flows. Specially, researchers have concluded that knowledge stocks that are build, adapted and leveraged through num erous learning flows (Diericks and Cool, 1999; Sanch ez, 2001; Crossan et al., 1999; Bontis et al., 2002). In addition, while there's no agreem ent about the specific role of learning flows on business performance, it is considered that an organization's knowledge stock is likely the main force to succeed in the satisfaction of environmental requirements, which leads to improved non-financial business performance. Furthermore, non-financial performance is also an antecedent of financial performance (Prieto and Revilla, 2004). It is also suggested that the business performance, and in particular the $f$ inancial performance, is not an ultim ate consequence of the knowledge stocks, but provide s important feedback about the efficiency of learning flows and, ultimately, affects how an organisation continues to learn (Mintzberg et al., 1995; Dragonetti \& Roos, 1998). Therefore, desp ite we will not examine this link, we can point out that the capacity to learn in organisa tions is not simply a collector of knowledge but a processor of it which influences the degree to which organisations are likely to prom ote continuous learning as a long-lasting core competency (Calantone et al., 2002).

$<$ Insert figure 1 about here $>$

\section{The learning capability and its essential dimensions}

Although many authors on organizational learning have im plicitly shown the im portance of the learning capability, it is dif ficult to $f$ ind an explicit def inition of the concept. Descriptions about the organizational potentia 1 to learn are often $\mathrm{m}$ ade through the link between knowledge and learning processes (Die rickx and Cool, 1989; Decarolis \& Deeds, 1999; Bontis et al., 2002). Knowledge is an esta blished theoretical construct that has been proposed as heterogeneous resource that firm $\mathrm{s}$ value in different $\mathrm{m}$ anifestations (Amin and Cohendet, 2004). The $\mathrm{m}$ ain types of knowledge di stinguished in the literature are: explicit knowledge versus tacit knowledge, and individual knowledge versus collective knowledge. Together with it, it is also possible recognize two other dimensions of knowledge in order to explain the adaptative perform ance of firms (Blacker, 1995; Cook and Brown, 1999): knowledge as som ething that individuals, gr oups or organizations have (knowledge as cognitive possession) versus as som ething that individuals, groups and organizations do (knowledge as practice). Knowledge that is possessed has been studied from a cognitive viewpoint, while knowledge that is practice is the result of a behavioural perspective that introduces the study of "knowing". According to it, knowledge should be understood as multi-faceted, comprising cognition and actions, and existing at the individual, group and organizational level.

But knowledge existing within organizations needs to be continually renewed, integrated and translated into com petence (Elkjaer, 2001). It is thus necessary to develop learning processes as an essential requirem ent to produce new knowledge that, when engrosses the 
initial knowledge, will lead to adjustm ents in the original cognition, actions, or both (Vera and Crossan, 2003). Hence, even when they interact with one another throughout the organization, the learning processes and knowledge are two distinct but related concepts. Knowledge is the content of the learning pro cesses. In particular, it is argued that all organisations uphold a stock of knowledge that needs to continually flow through learning processes in order to fit environmental requirements. (Diericks and Cool, 1989; Coakes et al., 2004). The stock of knowledge refers to all th at is already known or needs to be known, which includes aspects of both cognition and action. The learning flows captures how the organization interacts with the organizationa 1 members and the environm ent (Nonaka and Toyama, 2003), and can be considered as the en acting processes of knowledge stocks so that new forms of knowledge em erge (Cook and Brown, 1999). These learning flows take knowledge stocks and result in new or $\mathrm{m}$ odified knowledge stocks for $\mathrm{m}$ aking sense of the word and taking action in it (Sanchez, 2001). Th en, learning flows constitutes a reinforcing mechanism for the original stocks of knowledge by continually leveraging different stocks of knowledge, tacit and explicit (Bontis et al., 2002).

To better understand the role of learni

ng flows and knowledge stocks within organisations, the concepts of exploration and exploitation have been considered especially constructive (March, 1991; Crossan at el., 1999). E xploration flows play an essential role in renewing the knowledge stocks necessary to co mpete in changing $\mathrm{m}$ arkets, but in doing so, also enhances a firm's existing knowledge. Thes e flows take place with the creation of new knowledge by individuals and the assim ilation of that knowledge, which happens when individuals share knowledge within groups un til being progressive institutionalised by the organisation. Exploitation flows reflect how th e firm harvests and incorporates existing knowledge into its activities while, at the sam e time, new knowledge $\mathrm{m}$ ay emerge from experience. These flows encom pass processes that transm it embedded organisational knowledge that has been learnt from the past down to the groups and organisational members. Therefore, the organizational learning capab ility is com prised by continually evolving knowledge stocks that continually flow both upward and downward all of individuals, groups and the overall organisation (Nonaka and Takeuchi, 1995; Crossan et al., 1999). The continuous reproduction between knowledge stoc ks and learning flows results in the reinforcement of existing stocks of knowledge in relation to new ideas. Learning flows are thus necessary to ensure that sticky knowledge is transformed into fluid knowledge (Coakes et al., 2004). Therefore, on the basis of previous ideas, we can form the following hypothesis:

Hypothesis 1: The higher the levels of learning flows developed in organisations, the higher the levels of knowledge stocks existing in the organisation.

\section{The learning capability and business performance: the key role of knowledge}

The development and flowing of knowledge stocks through learning is not an end by itself. It is regarded as a potential source of sustainable competitive advantage (Coakes et al., 2004), and thus it is pursued by organizations as an interm ediate stage that explains differences in perform ance. Researchers su stain different views about the link between learning flows, knowledge stocks and busine ss performance (Huber, 1991; Crossan et al., 1995). Most of the research contributions de fend a neutral-to-positive link between learning 
flows and performance (Crossan et al., 1995; B ontis et al., 2002), but state that knowledge stocks are sure precedents for better perform ance (Stewart, 1997; Bontis et al., 2002). Then, while the direct relationship between the learning flows and business perform ance is controversial, it is considered that effects of the learning capacity on organisational performance are mainly derived from the knowledge stocks.

Really, organisations that want to enhance business perform ance need to nurture the capabilities they need to grow and $\mathrm{m}$ aintain their competitive advantages. These capabilities are underpinned by knowledge (Marr and Schiuma, 2001) and, then, knowledge stocks can be considered a precondition for the organisati on's success. Knowledge im pact on business performance has been exam ined by several studies (Appleyard, 1996; Argote and Ingram , 2000; Prieto, 2003; Soo et al., 2004) that argue that knowledge, in am ount or quality, form s the basis of com petitive advantage in organi zations. Conversely, there is no com plete nor ideal way to m easure business performance and, then, to measure the effects of the learning capacity. The idea of the realistic existen ce of a positive link between the knowledge and business performance often relates the potential effects to the economic and financial success and, in fact, it is possible to use some kind of indicators about the financial success. However, business performance is a $\mathrm{m}$ ultidimensional concept, nor easily $\mathrm{m}$ easurable and $\mathrm{m}$ ore complex than the financial ratios and indicators usually applied. Then, the potential effects of knowledge on business perform ance cannot be determined exclusively by a financial assessment linked to a pyram id of financial ratios (Kennerley and Neely, 2000). Effects also deal with the reaction of others (e.g. custom ers, employees, etc.) to the actions of the organisation. This reaction will be better wh en the organisation has knowledge im proved by its learning potential and this knowledge guides the fulfilment of others' expectations along with the organisation's purposes.

In fact, there is an only way to enlarge an organization's financial performance, and it is through the identification and satisfaction of market demands (Neely and Adams, 2001). To a great extent, this satisfaction relies on cust omers' perception about the organization's activities, products or the value of service. Th en, customers' perceptions will be im proved to the extend in which organizations develop its ability to offer them its active knowledge (in the form of products, services and processes), satisfying their needs and strengthening the established relations. In other words, the orga nisation must have knowledge of how to serve the market in order to recognize solutions to customer needs, provide them a vital service, and make it harder for them to switch to another supplier. As stated by num erous studies (Slater and Narver, 1995; Saint Onge, 2002), a strong c onnection exists between the quality of the relationships and custom er satisfaction, the dur ability of the relationships and the resulting profitability. Thus, if established relations with customers prosper, it is only a question of time to gain a positive result on the financial performance.

The need for non-financial $\mathrm{m}$ easures in or der to assess a com pany's knowledge-based success is recognized in $\mathrm{m}$ any popular perform ance management and $\mathrm{m}$ easurement frameworks that have started to introduce new measures. In example, the numerous efforts to measure intellectual capital in organisations have included several discussions about performance measurement arguing that it is $n$ ecessary to balance the traditional econom ic valuation with the non-financial valuation of organisational perform ance (Stewart, 1997; 
Martin, 2000; Carlucci et al., 2002). Kaplan and Norton (1992; 1996) proposed their fam ous Balanced Scorecard, providing a m ulti-dimensional corporate m easurement system, which includes financials, custom ers, internal processes plus innovation and learning. The EFQM Excellence Model have im pacted the corporate $m$ easurement agenda by encouraging that customers results, employees and impact on society results are key perform ance results that must be considered as the $\mathrm{m}$ ain performance criteria (what an organisation achieves). The Skandia Navigator is also centred on the "H uman focus" (Edvinsson and Malone, 1997). And a more recent $m$ easurement model, the Pe rformance Prism by Neely and Adam s (2001), explicitly adopts a stakeholder centric view of performance measurement together with more traditional aspects of perform ance measurement. The stakeholder view considers that, together with custom ers, modern business e nvironment is characterized with increased importance and strength of em ployees and soci ety in general. Then, it includes custom er loyalty, company names and brand image, and other fundamental links between.

Therefore, companies having a superior know ledge base are able to coordinate and combine their traditional resources and capab ilities in new and distinctive ways, providing more value for their customers and, in general, stakeholders than can their competitors (Teece et al., 1997). Then, the knowledge stocks are pr oposed to affect the non-financial business performance and, accordingly, the following hypothesis is set forth:

Hypothesis 2: The higher the levels of the knowledge stocks existing in organisations, the higher the levels of the non-financial performance generated in the organisation.

\section{Non-financial performance and financial performance}

Even when firm 's financial perform ance is influenced by num erous factors (econom ic conditions, changing government regulations which may favour one com pany over another, technological developments, changes in the co st of producing and delivering products or services due to macro-economic shifts, etc), it seems rather reasonable to think that there may exist a significant direct relationship between a company's overall stakeholders' satisfaction and the financial performance. Generally, non-financial performance has no intrinsic value for companies' directors. Rather, this non-financ ial performance can be used as a leading indicator of financial perform ance and, specially, future financial perform ance that is not contained in contem porary accounting measures. In marketing, a fruitful stream of research has identified a strong positive link between customer satisfaction, $m$ arket share and profitability (Capon et al., 1990; Anderson et al., 1994; Anderson and Fornell, 2000). Customers' satisfaction may mean more customers will purchase and repurchase in the future. Satisfied customers are likely to buy more frequent and in a greater volume and acquire other products and services offered by the com pany. In addition, consistently providing products and services that satisfy custom ers should increase the financial perform ance by reducing failure cost. And the more the number of customers, the more the organisational profitability. Similarly, if a firm has strong employees' satisfaction, it should be reflected in the company's economic returns because it involves a better e fficiency and productivity. Moreover, the cost of attracting new custom ers or employees should be lower for organisations that achieve a high level of reputation. A high reputation can also lead to introduce new products and services by reducing the buyer's risk of trial (Anderson et al., 1994). And reputation also can 
be beneficial in establishing and maintaining relationships with key suppliers, distributors and potential allies (Anderson et al., 1994). In accordan ce, our last purpose is to exam ine if the non-financial performance can be considered a precedent of the long-term financial returns.

Hypothesis 3: The higher the levels of non-financial performance, the higher the levels of financial performance. 


\section{EMPIRICAL RESEARCH}

\section{Data collection and sample characteristics}

Survey methodology has been used for the em pirical analysis. The questionnaire has been designed and developed from a thorough literatu re review, and sim plified by us in som e indicators. The questionnaire was validated th rough a pre-test that was carried out through several personal interviews with senior $m$ anagers. These interviews allowed us to clarify our survey items and rectify any potential deficiency. Minor adjustm ents were made on the basis of specific suggestions.

The questionnaire was then administered to a random sample of 1.064 Spanish Companies randomly selected on the basis of the database Duns \& Bradstreet (50.000 Main Spanish Companies, 2000). Our sam ple consists of companies reporting between 50 and 2.500 employees. Sampled firms fit into activities - f rom industry and service- facing dynam ic and competitive environments, covering a wide enough range so as not to restrain the scope of analysis. Sample selection mainly was moved for two reasons. First, we have tried to target companies where issues of knowledge and learni ng are generally recognized as relevant and general. Second, we use a diverse sam ple to increase the generality of results. Mail surveys were sent to the CEO of the company or a reasonable substitute such as the Hum an Resource Manager (mainly for large companies), who have been identified as key respondents based on two criteria (Andreu and Solé Parellada, 2001; Gardiner and Leat, 2001; Bontis et al., 2002): (a) possession of sufficient knowledge and (b) ade quate level of involvem ent with regard of the issues being investigated. To asses th e degree to which com mon method bias $\mathrm{m}$ ight present a problem, we subjected all scale item $\mathrm{s}$ for similar constructs to a $\mathrm{f}$ actorial analysis with a varimax rotation (Seibert et al., 2001; Tippins and Sohi, 2003). Results indicated that the items loaded cleanly on the factors repres enting the expected constructs. Thus, we found no general factor that would have emerged due to common method variance.

Table 1 sum marizes the respondent characteris tics in term $\mathrm{s}$ of industry type and total number of employees. A total of 111 surveys were returned, representing a $10.52 \%$ response rate. Respondents were fairly distributed acr oss manufacturing $(8,88$ per cent) and services $(10,93$ per cent). Firm size was also quite well distributed, with the exception of com panies ranging between 100 and 250 employees, which represent a major group, and companies with less than 50 employees, which represent a marginal group.

$<$ Insert table 1 about here $>$

\section{Measures description}

The measurement of the analysis variables has been built on a $\mathrm{m}$ ultiple-items method, which enhances confidence about the accuracy a nd consistency of the assessm ent. Each item was based on a five point Likert scale and all of them are perceptual variables. Table 2 displays items used to measure the analysis variables.

$<$ Insert table 2 about here $>$ 


\section{Learning capability}

We have modeled the learning capability in organizations as a multidimensional construct in which knowledge stocks and learning flows ar e considered as representative dim ensions. Both knowledge stocks and learning flows are tr eated as first-order indicators of the secondorder construct, the learning capability.

In particular, we have considered that knowle dge stocks in organizations exist at several levels (Nonaka and Takeuchi, 1995; Crossan et al., 1999): the individual, the group and the organizational levels. Obviously, organizations learn through their individual members, which develop knowledge through their own personal experiences (Nonaka and Takeuchi, 1995). Some individual knowledge $\mathrm{m}$ ay be applied direc tly to perform the assigned task, but $\mathrm{m}$ uch individual knowledge must be shared with other individuals in a group before that knowledge becomes a basis for taking action (Sanchez, 2001). This way, individuals inside groups develop knowledge in common in order to perfor $m$ tasks in a coordinated fashion. Sim ilarly, groups in an organization interact, com municate their knowledge to other groups and acquire other knowledge required to put their own knowledge into action. As a result, individuals and groups play an im portant role in the integra tion of some knowledge in the organization in such a way that knowledge is em bedded in the organization's systems, routines and values (Nonaka and Takeuchi, 1995; Sanchez, 2001). Accordingly, we have measured the knowledge stocks by including 15 item s: five item s pertaining to the individual stocks, five item $\mathrm{s}$ for group stocks and five items for the organizational stocks of knowledge. Most of the $m$ easures were adopted from relevant literature, especially Bontis et al. (2002).

In the same way, we have $m$ entioned that learning flows in organizations are aim ed at both the exploration and the exploitation of knowledge. As stated by Crossan et al. (1999), exploration flows take place when individua 1 members generate new knowledge, and groups and the organization progressively integrates it. Exploitation flows encom passes processes that take and transmit embedded organizational knowledge that has been learnt from the past down to groups and individual members. Accordingly, learning flows have been measured by using 10 item $\mathrm{s}$, five of them pertaining to expl oration flows and five item $\mathrm{s}$ to exploitation flows. Once more, these items are mainly based in Bontis et al. (2002) research.

\section{Business performance}

As we have previously argued, we have $m$ easured business performance from a financial and non-financial perspective. Identifying optim al measures for business perform ance is inherently problematic, and there is not an only nor upper measure to assess the global impact of the learning capability on business perform ance. In this study, we adopt two variables modelled as uni-dim ensional constructs with $\mathrm{m}$ ultiple-indicator measures. Non-financial performance has been measured addressing issues such as customer's satisfaction (Ellinger et al., 2002), num ber of custom er's growth (Kaplan and Norton, 1996; Saint Onge, 2002), employee's satisfaction (Johansson et al., 1998; EFQM, 2001, Goh and Ryan, 2002) and the organizational reputation (EFQ M, 2001; Bontis et al., 2002). Financial performance is described through return on assets (Bierley and Chakrabarty, 1996; Calantone et al., 2002; Ellinger et al., 2002; Goh and Ryan, 2002), sale s growth (Tippins and Sohi, 2003), overall profitability (Johansson et al., 1998; Tippins and Sohi, 2003), average productivity (Vekstein, 1998; Ellinger et al., 2002) and cost reduction (Ellinger et al., 2002). 


\section{ANALYSIS AND RESULTS}

\section{Psychosometric proprieties of measurement scales}

Figure 1 illustrates the proposed latent variab le model, showing all structural paths. Before testing this model, a series of test was performed to asses the unidimensionality of the measures. Because multiple-item construct measures variables, and to verify that items tapped into their stipulated construct, a conf irmatory factorial analysis (CFA) was em ployed to determine the validity of the constructs.

Table 3 summarizes the number of items and the results of the reliability and validity test for the analysis variables. The internal c onsistency measures (Cronbach's alpha) were obtained in order to assess the reliability of the m easurement instruments. Three separate confirmatory factor analysis were conducte $d$ by using LISREL 8: two corresponding to each of the broad dim ensions of the learning capab ility (the sets of constructs $f$ or both the knowledge stocks and learning flows), and one more for business perform ance. The paths were examined using t-statistics (for expected factor loadings), whereas paths that were not specified were evaluated using standardized residuals and $\mathrm{m}$ odification indices. Based on these statistics and theoretical considerations we deleted item $\mathrm{s}$ if appropriate (Anderson and Gerbing, 1988). Convergent validity was established by confirming that all scale items loaded significantly on their hypothesized construc ts factors (Anderson and Gerbing, 1988). Discriminant validity was assessed by com paring the $\chi^{2}$ differences between a constrained CFA (where the interf actor correlation was set to 1 , indicating they are the sam e construct) and an unconstrained $\mathrm{m}$ odel (where the interfactor correlation was $\mathrm{f}$ ree). All $\chi^{2}$ differences were found to be significant, providing suppor $\mathrm{t}$ for discrim inant validity (Anderson and Gerbing, 1988). Overall, the fit of the m odels were good, with GFI, AGFI, RMR and CFI all within recommended values.

We have previously def ined learning capability is a higher order construct com posed of knowledge stocks and learning flows. To c onfirm the $\mathrm{m}$ ultidimensionality of the learning capability as a higher-order construct we ran a second-order CFA. Table 3 shows how the loadings of the $\mathrm{m}$ easurement items on the firs $\mathrm{t}$-order factors, and the loadings of the measurement items of he first-order factors (knowledge stocks and learning flows) on the second-order factor (learning capability) were all significant ( $p \leq 0.005)$. Further, the goodness of fit indices was also excellent. This second-order CFA was estimated by resuming in single factors the indicators of the knowle dge stocks construct (individuals, group and organizational stocks) and the learning flows c onstruct (exploration and exploitation) through principal components analysis (using SPSS 10.0 for Windows).

$<$ Insert table 3 about here $>$

\section{Results of path analysis}

We use a structural equation model (conducted by LISREL 8) to determine the significant paths between the learning capability, non-financia 1 performance and financial perform ance. This analysis has been conducted in view of the preceding confirmatory analysis. Then, fixed 
lambda values ( $\lambda \mathrm{ij})$ and m easurement error variances are specified a priori in base to the previous measurement models estimations. Results are shown in Figure 2, which illustrates the estimated path coefficients and their associ ated t-values (in parenthesis) as well as the goodness of fit indices (which prove a good fit for the model).

\section{$<$ Insert figure 2 about here $>$}

All proposed paths are significant. First, th e path coefficient from learning flows to knowledge stocks is 0.994 , which supports th e existence of a strong and significant link $(\mathrm{t}=$ 11.982, $\mathrm{p}<0.05$ ) as stated in our hypothesis $1 . \mathrm{T}$ hus, learning flows support and im prove adequate knowledge stocks, so that a dependence relationship exists between both dimensions in order to develop a learning capacity. S econd, we can also observe the positive and statistically significant coefficient $(\mathrm{t}=9.086, \mathrm{p}<0.05)$ on the path from knowledge stocks to non-financial performance, which reveals a link between both constructs. So, knowledge stocks significantly affect non-financial performance, which supports hypothesis 2 . Finally, the significant $(\mathrm{t}=4.606, \mathrm{p}<0.05)$ path coefficient from non-financial performance to financial performance is 0.471 and, then, non-financial perform ance grounds the financial success as suggested in hypothesis 3 . 


\section{DISCUSSION}

This research has exam ined the link be tween the learning capacity and business performance. Our empirical analysis has the following contributions. First, it is established a measurement model for the learning capacity in terms of learning flows (exploration and exploitation) and knowledge stocks (individual, group and organizational stocks). Second, it is empirically tested the statistically significant and positive link existing between the learning flows, the knowledge stocks and business perf ormance, in both non-financial and financial terms. In particular, it is shown that lear ning flows strongly guide the im provement of knowledge stocks, which, in its turn, generate a non-financial performance as a precedent for a financial one.

First of all, learning capability is confirm ed as a higher-order construct that involves both knowledge stocks and learning flows. The knowledge stocks include all that is already known or needs to be known -knowledge and knowing-, and the learning flows are $\mathrm{m}$ ore concerned with the relationship between knowledge and knowing at the individual, group and organizational levels. Following the scale deve lopment of Bontis et al. (2002), this study strongly supports the original conceptualizati on of the construct so that learning capability can't be understood without one or another. However, future explore should explore knowledge stocks and learning flows sub-di mensions thoroughly. Second, we confirm the existence of a link between the learning capac ity and business perform ance, which (1) is derived from knowledge stocks, but in such a way that learning flows strongly act as an improving mechanism on the knowledge stocks; and (2) the success of the learning capability must be assessed through non-financial and financial measures of business performance.

In fact, there is a strong link between the learning flows and the knowledge stocks, which is no surprising if considering both of them as dimensions of the learning capability. Learning flows are necessary for the creation, integra tion, transformation and utilization of knowledge stocks as a previous and necessary step for knowledge to yield positive results. Moreover, the effectiveness of the learning flows can be a ssessed on the basis of their purpose of guiding knowledge towards the creation of value. W ithout learning flows, knowledge stocks may loose their value. Hence, to build a real learning capacity, the relevant problem for practitioners when managing knowledge is to en act multiple learning flows that constantly sustain and leverage key knowledge stocks for the organisational success. In this sense, knowledge management can be considered as an essential enabler for this dual knowledge leveraging and, then, to extract from knowledge a performance advantage.

In addition to previous argum ents, we have established that there is no a straight forward link between learning flows and business perform ance, but rather a $\mathrm{m}$ ore complex relationship in which knowledge stocks are a necessary "middle step". Organisations can initiate learning flows almost instantaneously, but it does not $\mathrm{m}$ ean that directly learning yields a positive result. Positive results em erge from knowledge stocks, which are not instantaneous but an enduring result of learning flows. These knowledge stocks are the ground of the organisational capabilities require $d$ to efficiently develop the com pany's processes, products and value of service, a nd thus, knowledge stocks strongly determ ine the organizational potential to create value for st akeholders as a precondition of financial 
achievements. It is thus highlighted the pos itive relationship between knowledge stocks and the non-financial business perform ance -always considering that knowledge stocks $m$ ust regularly evolve through learning flows in order to $\mathrm{m}$ aintain that level of com petence along time-. Specifically, managers play a key role in deciding which knowledge is relevant to be aware of and solve those custom er's problems that $m$ ay constitute a $m$ arket opportunity. Those who lack this knowledge will find it diffi cult to form ulate an effective strategy to introduce and sell new products/services in such a way that value for stakeholders is created.

Finally, we have also found the existence of a significant link between the non-financial performance and the financial perform ance. However, this link is weaker in $\mathrm{m}$ agnitude than the previous ones cause, in fact, reported financial performance is influenced by many factors over time (i.e., econom ic environment, competitors' actions, technological developm ents, etc). Likewise, we think this weaker link reveals that $m$ anifestations of financial improvements from improving non-financial pe rformance may not occur in the sam e proportion nor instantaneously. Managers $m$ ust thus realise that satisfied custom ers and stakeholders may not be autom atically profitable and, $m$ oreover, that satisfied custom ers (stakeholders) are not always profitable ones. Because efforts to increase current stakeholders' satisfaction primarily affect future actions and behaviours, the greater portion of economic returns from improving stakeholders' satisfaction also will be realised in subsequent periods. This all im plies that a long-run perspective $\mathrm{m}$ ay be necessary for evaluating the overall effects of learning and knowledge on business performance. Likewise, stakeholders' profitability and, then, the financ ial value of the learning capability $m$ ay be dependent on characteristics and contextual conditions such as the organizational age (Calantone et al., 2002), industry type (Choi and Lee, 2003), market power (Tippins and Sohi, 2003), entrepreneurial orientation (Wiklund and Sheperd, 2003), and environment dynamism.

In summary, the relevant problem for practitioners is to enact a learning capacity by promoting multiple learning flows that constan tly sustain the knowledge stocks required for creating value for stakeholders. Stakeholders $m$ ust be considered crucial for organizational success, and com panies that really care for th eir stakeholders dem onstrate better financial performance. Moreover, managers must neither forget that, first, the collection of a worthy knowledge stocks is not immediate, but a result derived from the enactment of learning flows along time, and second, that satisfied customers (stakeholders) are not always profitable ones.

We can thus presum e that the organizational ability to learn is not an im mediate determinant of superior business performance, but it comes to happen on the long-term. 


\section{LIMITATIONS AND FUTURE RESEARCH}

This study is subject to a num ber of lim itations that need to be addressed. As a first limitation, this study em phasizes the im portance of learning capability for business performance, but does not address the issue of how learning capability should be carried out. Future research could identify the anteced ents of learning capability and construct a comprehensible framework of both antecedents and consequences. Literature suggest the importance of knowledge m anagement for business performance (Carlucci et al., 2002; Vera \& Crossan, 2003), so we think the analysis of knowledge m anagement as enabler of the learning capability could manifest the mediator role of learning capability between knowledge management and perform ance. It could be also considered the $\mathrm{m}$ oderating effect of knowledge management on the relationship betw een learning flows, knowledge stocks and business performance.

Second, like most social science models, our model excludes some potentially important factors. We have only considered knowledge stocks as a general construct, but we could have differentiated between individual knowle dge stocks, group knowledge stocks and organizational knowledge stocks. To prevent the analysis for being overwhelmingly complex, we did not include previous factors that $\mathrm{m}$ ight be enlightening of the effects of knowledge stocks on business performance.

Third, our study contributes to learning capab ility assessment by dem onstrating that is possible to measure theoretical relevant constr ucts that are unobservable. But even when we have tried to define our constructs as precise ly as possible by drawing on relevant literature, and to closely link our $\mathrm{m}$ easures to their theoretical underpinnings, the $\mathrm{m}$ easurement items used here can realistically be thought of as only proxies for an underlying and latent phenomenon that is neither fully nor easily measurable. In this sense, although the measure of organizational stocks as a construct of knowledge stocks performed satisfactory, its reliability was above 0.6 but below 0.7 . Moreover, the adjusted $\mathrm{m}$ easurement model uses only three perceptual items to valuate non-financial perform ance and financial perform ance. While this is considered adequate for confirm atory factor analysis using LISREL, the use of additional and objective items might help capture the rich constructs to a greater extend. Future research should then keep on the search and validation of a superior measure of learning capability.

Another limitation comes from single inform ants used as the source of inform ation. Respondents were Hum an Resource Managers and, on default, CEOs. Although the use of these single inf ormants remains the prim ary research design in $m$ ost studies, $m$ ultiple informants would enhance the validity of the research findings. While one can expect these managers to have a great deal of knowledge about the topics being evaluated, their outlook could be excessively narrow or even inclined to overrate what reality is. Replies $\mathrm{f}$ rom multiple respondents and the obtaining of objec tive data-especially outcom e measureswould have significantly enhanced the present research.

Finally, in this paper business perform ance was the organizational outcome and, hence, a dependent variable. But future research should attempt to assess the degree in which business performance provides im portant feedback about the efficiency of learning capability and, 
ultimately, enables future learning capability. The purpose should be to test the existence of a retroactive effect that ties learning capability and performance in a continuous loop. Research on this issue $\mathrm{m}$ ay require a longitudinal appr oach by noticing the evolution of learning capability and business performance over time. Longitudinal data should also instigate a more exhaustive study of the relationship between learning capability and superior perform ance over time, and specially, an analysis of the relationship between financial perform ance and non-financial performance. This is especially true since some of the effects included on the model seem to take tim e to occur. This study could not assess the nature of such tim e lags, due to its cross sectional nature. 


\section{TABLES AND GRAPHAS}

Figure 1. A model linking the learning capacity and business performance

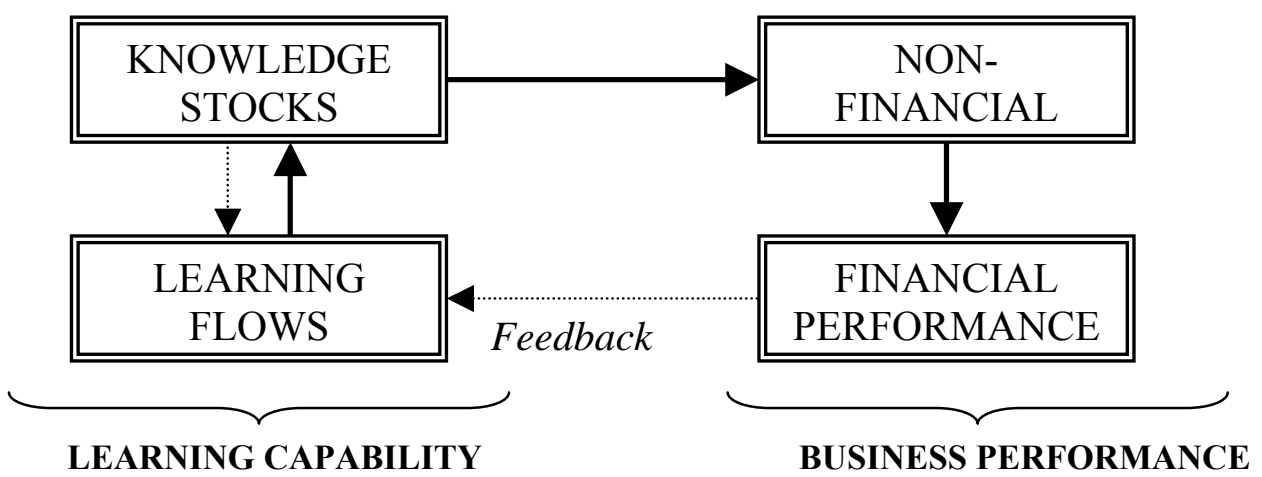

Figure 2. Structural equation model

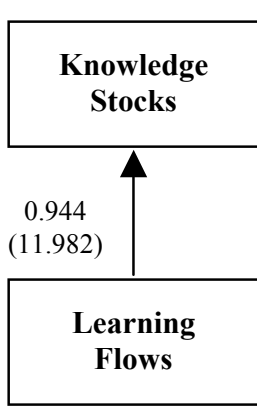

LEARNING CAPACITY

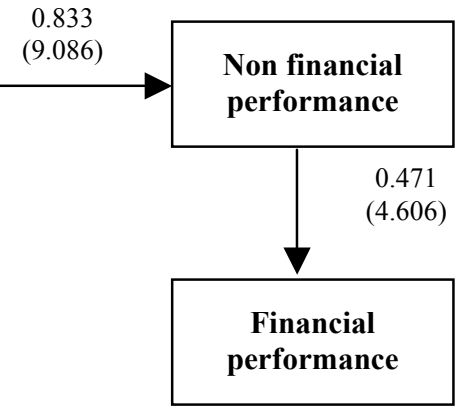

BUSINESS PEFORMANCE $\chi^{2}(79)=70.379$

$(\mathrm{P}=0.147)$

$\mathrm{GFI}=0.905$

$\mathrm{AGFI}=0.894$

$\mathrm{RMR}=0.0706$

$\mathrm{CFI}=0.982$ 
Table 1. Respondent characteristics

\begin{tabular}{|l|c|c|c|}
\hline \multicolumn{1}{|c|}{ INDUSTRY TYPE } & $\mathbf{N}^{\mathbf{0}}$ responses & $\begin{array}{c}\text { \% Over each } \\
\text { industry sample }\end{array}$ & $\begin{array}{c}\text { \% Over the total } \\
\text { sample }\end{array}$ \\
\hline Manufacturing (chemistry, petroleum and others) & 15 & $9,09 \%$ & $13,39 \%$ \\
Miner & 4 & $8,16 \%$ & $3,57 \%$ \\
Total industry activity & $\mathbf{1 9}$ & $\mathbf{8 , 8 8 \%}$ & $\mathbf{1 6 , 9 6 \%}$ \\
Transport, communications and public services & 5 & $2,77 \%$ & $4,46 \%$ \\
Services & 59 & $16,66 \%$ & $52,67 \%$ \\
Financing and insurance & 28 & $9,39 \%$ & $25 \%$ \\
Total service activity & $\mathbf{9 2}$ & $\mathbf{1 0 , 9 3 \%}$ & $\mathbf{8 3 , 2 1 \%}$ \\
TOTAL & $\mathbf{1 1 1}$ & $\mathbf{1 0 , 5 2 \%}$ & $\mathbf{1 0 0 \%}$ \\
\hline & & & $7,2 \%$ \\
\hline$<50$ & 8 & $5,5 \%$ & $13,51 \%$ \\
50 a $\leq 100$ & 15 & $19,26 \%$ & $40,54 \%$ \\
100 a $\leq 250$ & 45 & $34,86 \%$ & $14,41 \%$ \\
250 a $\leq 500$ & 16 & $15,59 \%$ & $12,61 \%$ \\
500 a $\leq 1000$ & 14 & $12,84 \%$ & $11,71 \%$ \\
$\geq 1000$ & 13 & $11,92 \%$ & $\mathbf{1 0 0 \%}$ \\
TOTAL & $\mathbf{1 1 1}$ & & \\
\hline
\end{tabular}

Table 2. Variables Definition and Sample Survey Items

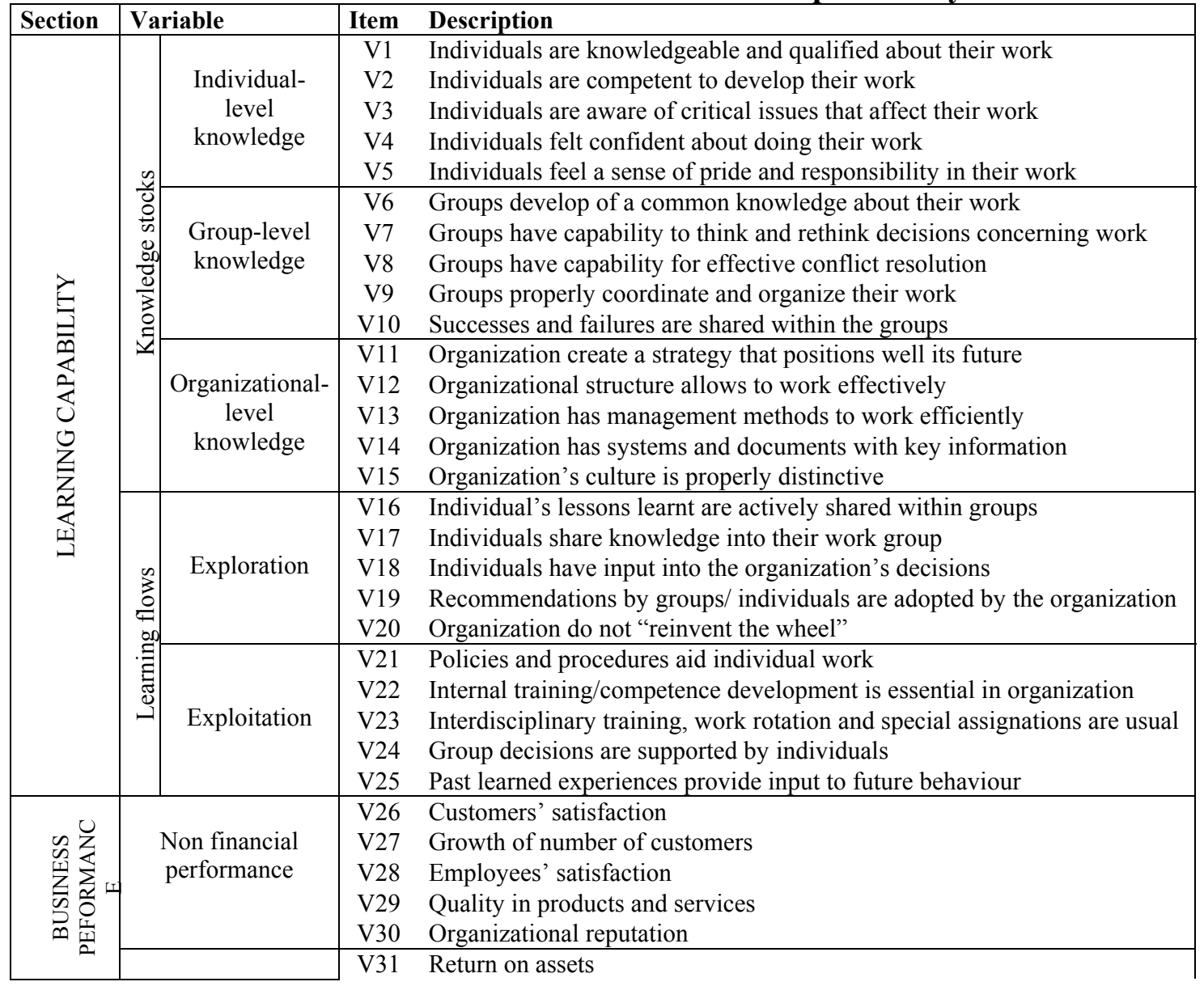




\begin{tabular}{|l|l|ll|}
\hline & Financial & V32 & Sales growth \\
& performance & V33 & Profitability \\
& & V34 & Improvement in work productivity \\
& & V35 & Improvement in production cost \\
\hline
\end{tabular}

Table 3. Results of reliability and validity for the measures

\begin{tabular}{|c|c|c|c|c|c|}
\hline Paths & $\begin{array}{c}\text { Standardiz } \\
\text { ed } \\
\text { loadings }\end{array}$ & t-values & $\begin{array}{l}\text { Goodness of fit } \\
\text { indices }\end{array}$ & $\begin{array}{c}\text { Reliability } \\
\text { (Cronbach } \\
\alpha)\end{array}$ & Constructs correlation \\
\hline 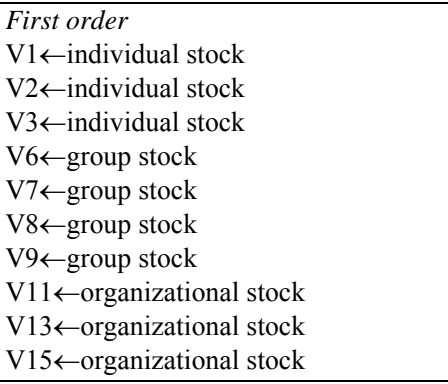 & $\begin{array}{l}0.670 \\
0.822 \\
0.707 \\
0.616 \\
0.826 \\
0.711 \\
0.614 \\
0.532 \\
0.745 \\
0.586\end{array}$ & $\begin{array}{l}7.124 \\
9.022 \\
7.579 \\
6.664 \\
9.818 \\
8.015 \\
6.648 \\
5.346 \\
7.728 \\
5.991\end{array}$ & $\begin{array}{c}\chi^{2}=35.376 \\
(\mathrm{P}=0.312) \\
\mathrm{GFI}=0.940 \\
\mathrm{AGFI}=0.896 \\
\mathrm{RMR}=0.0510 \\
\mathrm{CFI}=0.990\end{array}$ & $\begin{array}{l}0.757 \\
0.782\end{array}$ & $\begin{array}{c}\phi_{\mathrm{IG}}=0.597 \\
(6.897) \\
\phi_{\mathrm{IO}}=0.513 \\
(4.785) \\
\phi_{\mathrm{GO}}=0.873 \\
(12.725)\end{array}$ \\
\hline 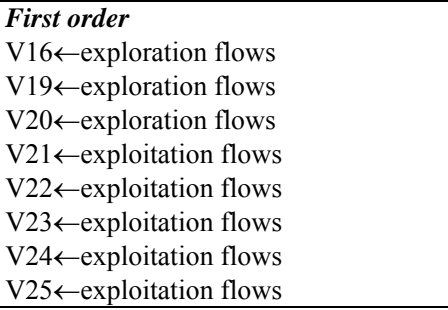 & $\begin{array}{l}0.662 \\
0.753 \\
0.798 \\
0.607 \\
0.641 \\
0.549 \\
0.584 \\
0.530\end{array}$ & $\begin{array}{l}7.060 \\
8.321 \\
8.976 \\
6.199 \\
6.613 \\
5.504 \\
5.917 \\
5.278\end{array}$ & $\begin{array}{c}\chi^{2}=21.391 \\
(\mathrm{P}=0.316) \\
\mathrm{GFI}=0.952 \\
\text { AGFI }=0.909 \\
\mathrm{RMR}=0.0472 \\
\mathrm{CFI}=0.990\end{array}$ & 0.775 & $\begin{array}{c}\phi=0.867 \\
(13.589)\end{array}$ \\
\hline $\begin{array}{l}\text { First order } \\
\text { V } 26 \leftarrow \text { not financial performance } \\
\text { V } 28 \leftarrow \text { not financial performance } \\
\text { V } 30 \leftarrow \text { not financial performance } \\
\text { V } 31 \leftarrow \text { financial performance } \\
\text { V } 32 \leftarrow \text { financial performance } \\
\text { V33 } \leftarrow \text { financial performance }\end{array}$ & $\begin{array}{l}0.595 \\
0.665 \\
0.801 \\
0.853 \\
0.803 \\
0.929\end{array}$ & $\begin{array}{c}5.808 \\
6.520 \\
7.833 \\
10.536 \\
9.669 \\
11.997\end{array}$ & $\begin{array}{c}\chi^{2}=7.553 \\
(\mathrm{P}=0.478) \\
\text { GFI }=0.978 \\
\text { AGFI }=0.941 \\
\text { RMR }=0.0211 \\
\text { CFI }=1.000\end{array}$ & 0.722 & $\begin{array}{c}\phi=0.486 \\
(5.105)\end{array}$ \\
\hline $\begin{array}{l}\text { Second order } \\
\text { individual stock } \leftarrow \text { knowledge stocks } \\
\text { group stock } \leftarrow \text { knowledge stocks } \\
\text { organization stock } \leftarrow \text { knowledge stock } \\
\text { exploration flows } \leftarrow \text { learning flows } \\
\text { exploitation flows } \leftarrow \text { learning flows } \\
\text { learning flows } \leftarrow \text { learning capacity } \\
\text { knowledge stocks } \leftarrow \text { learning capacity }\end{array}$ & $\begin{array}{l}0.461 \\
0.712 \\
0.859 \\
0.888 \\
0.748 \\
0.951 \\
0.997\end{array}$ & & $\begin{array}{c}\chi^{2}=2.752 \\
(\mathrm{P}=0.431) \\
\mathrm{GFI}=0.990 \\
\mathrm{AGFI}=0.952 \\
\mathrm{RMR}=0.0169 \\
\mathrm{CFI}=1.000\end{array}$ & 0.747 & \\
\hline
\end{tabular}




\section{REFERENCES}

Amin, A. and Cohendet, P. (2004). Architectures of Knowledge. Firms, Capabilities and Communities. Oxford University Press.

Anderson, E.W., Fornell, C. \& Lehm an, D.R. (1994). "Custom er Satisfaction, Market Share, and Profitability: Findings from Sweden”. Journal of Marketing, 58, July.

Anderson, E.W. and Fornell, C. (2000). "Foundations of the Am erican Customer Satisfaction Index". Total Quality Management, 11 (6): 869-882.

Anderson, J.C. and Gerbing, D.W . (1988). "Structural Equation Modeling in Practice: A Review and Recommended Two-Step Approach". Psychollogical Bulletin, 13 (3): 411-423.

Andreu Bench, M. and Solé Parellada, F. (2001). "The Actual State of Knowledge management in Spain: Utilization Prof iles and Field $\mathrm{f}$ or Improvement". Universitat de Barcelona.

Appleyard, M. (1996). "How Does Knowle dge Flow?. Interfirm Patterns in the Semiconductor Industry”. Strategic Management Journal, 17: 137-154.

Argote, L. and Ingram , P. (2000). "Know ledge Transfer: A Basis for Com petitive Advantage in Firms". Organizational Behaviour and Human Decision Processes, 82 (1): 150169.

Bierley, P. and Chakrabarti, A. (1996). "Gen eric Knowledge Strategies in the U.S. Pharmaceutical Industry”. Strategic Management Journal, 17 (winter special issue): 123-135.

Blacker, F. (1995). “Knowledge, Knowledge W ork and Organizations: An Overview and Interpretation”. Organization Studies, 16 (6): 1021-1046.

Bontis, N., Crossan, M. and Hulland, J. ( 2002). "Managing an Organizational Learning System by Aligning Stocks and Flows". Journal of Management Studies, 39 (4): 437-470.

Calantone, R.J., Cavusgil, S.T. and Zha o, Y. (2002). "Learning orientation, Firm Innovation Capability, and Firm Performance". Industrial Marketing Management, 31: 515524.

Cangelosi, V.E. and Dill, W.R. (1965). "Organizational Learning Observations: Toward a Theory”. Administrative Science Quarterly, 10: 175-203.

Capon, N., Farley, J.U. and Hoening, S. (1990). "Determinants of Financial Performance: A Meta Analysis". Management Science, 26: 1143-1159.

Castaneda, L.W. (2000). "Intrafirm Knowledge Transfer: a Review and Assessm ent of Current Research". Presentation at the Annual Academy of Management Meeting in Toronto.

Cecez -Kecmanovic, D. (2004). "A Sensem aking Mode of Knowledge in Organizations: A Way of Understanding Knowledge Management and the Role of Inform ation Technologies". Knowledge Management Research \& Practice, 2: 155-168.

Choi, B. and Lee, H. (2003). “An Em pirical Investigation of Knowledge Managem ent Styles and their Effect on Corporate Performance". Information \& Management, 40: 403-417.

Choo, C.W. and Bontis, N. (2003). The Strategic Management of Intellectual Capital and Organizational Knowledge. Oxford University Press. 
Chuang, S. (2004). "A Resource-Based Pe rspective on Knowledge Managem ent Capability and Com petitive Advantage: An Em pirical Investigation". Expert Systems with Applications, 27: 459-465.

Coakes, E., Bradburn, A. and Sudgen, G. ( 2004). "Managing and Leveraging Knowledge for Organisational Advantage". Knowledge Management Research \& Practice, 2: 118-128.

Cook, S. and Brown, J.S. (1999). "Bridging Epistem ologies: The Generative dance Between Organizational Knowledge and Organizational Knowing". Organization Science, 10: 381-400.

Crossan, M., Lane, H.W., White, R.E. and Djurfeldt, L. (1995). "Organizational Learning: Dimensions for a Theory”. The International Journal of Organizational Analysis, 3 (4): 337360.

Crossan, M.M., Lane, H.W . and W hite, R.E. (1999). “An Organizational Learning Framework: from Intuition to Institution". Academy of Management Review, 24 (3): 522-537.

Decarolis, D.M. and Deeds, D.L. (1999). "The Impact of Stock and Flows of Organizational Knowledge on Firm Performance: an Em pirical Investigation of the Biotechnology Industry". Strategic Management Journal, 20: 953-968.

Dierickx, I. and Cool, K. (1989). "Assets St ocks Accumulation and Sustainability of Competitive Advantage”. Management Science, 35: 1504-1511.

Dragonetti, N.C. and Roos, G. (1998). "La Evaluación de Ausindustry y el Business Network Programme: una Perspectiva desde el Capital Intelectual". Boletín de Estudios Económicos, 53 (164): 265-280.

Edvinsson, L. and Malone, T. (1997). Intellectual Capital: Realising your Company's True Value by Finding its Hidden Brainpower. Harper Business, New York.

EFQM (2001). “The EFQM Excellence Model”. www. efqm.org/imodel/modelintro.

Elkjaer, B. (1991). "The Learning Orga nization: An Undelivered Promise”. Management Learning, 32 (4): 437-452.

Ellinger, A. D., Ellinger, A. E., Yang, B. and Howton, S.W . (2002). "The Relationship Between the learning Organization Concep $t$ and Firm s' Financial Perform ance". Human resource Development Quarterly, 13 (1): 5-21.

Gardiner, P. and Leat, M. (2001). "Learning in Organizations: HR Im plications and Considerations". Human Resources Development International, 4 (3): 391-405.

Goh, S.C. and Ryan, P.J. (2002). "Learning Ca pability, Organizational Factors and Firm Performance". Presentation for the Third European Conference on Organizational Knowledge, Learning and Capabilities, Athens, Greece, April 5-6.

Grant, R. (1996). "Toward a Knowle dge-Based Theory of the Firm ". Strategic Management Journal, 17 (Winter special Issue): 199-122.

Huber, G.P. (1991). "Organizational Lear ning: the Contributing Processes and the Literatures". Organization Science, 2 (1), February: 88-115. 
Johansson, U., Eklöv, G., Holm gren, M. a nd Martesson, M. (1998). "Hum an Resource Costing and Accounting versus the Balanced Scorecard". School of Business. Stockholm University.

Kaplan, R.S. and Norton, D.P. (1992). "The Balance Scorecard-Measures that Drive Performance”. Harvard Business Review, 70 (1), January/February: 71-79.

Kaplan, R.S. and Norton, D.P. (1996). The Balanced Scorecard, Harvard Business School Press, Boston.

Kennerley, M. and Neely, A. D. (2000). "P erformance Measurement Frameworks - A Review. In: Performance Measure-ment-Past, Present, Future". Conference proceedings, edited by A.D. Neely. July 2000, Cambridge.

March, J.G. (1991). "Exploration and Expl oitation in Organizational Learning". Organization Science, 2 (1), February: 71-87.

Martin, J.M. (2000). "Approaches to the $m$ easurement of the Im pact of Knowledge Management Programs". Journal of Information Science, 26 (1): 21-27.

Marr, B. and Schium a, G. (2001). "Def ining Key Perform ance Indicators for Organisational Knowledge Assets". Second European Conference on Knowledge Management. November 2001, Bled, Slovenia.

Minzberg, H., Quinn, J.B. and Voyer, J. (1995). “ The Strategy Process”. Englewood Cliffs: NJ Prentice-Hall.

Neely, A. and Adams, C. (2001). "Perspectives on Performance: The Performance Prism". http: //www.som.cranfield.ac.uk/som/cbp/prismarticle.pdf.

Nonaka, I. and Takeuchi, H. (1995). The Knowledge Creating Company. Oxford University Press, New York.

Nonaka, I. and Toyam a, H. (2003). The Knowledge-Creating Theory revisited: Knowledge Creation as a Synthesizing process". Knowledge Management Research \& Practice, 1: 2-10.

Prieto, I. (2003). Una Valoración de la Gestión del Conocimiento para el Desarrollo de la Capacidad de Aprendizaje en las Organizaciones: Propuesta de un Modelo Integrador. Tesis Doctoral. Departamento de Econom ía y Adm inistración de Em presas, Universidad de Valladolid.

Prieto. I. and Revilla, E. (2004). “ Learning capacity and business performance: a measurement and research". En Neely, A., Kennerley, M. and W alters A. (eds.): Performance Measurement and Management: Public and Private. Cranfield University, UK. Pp. 603-610.

Saint-Onge, H. (2002). http: //www.knowinc.com/saint-onge

Sanchez, R. (2001). Knowledge Management and Organizational Competence. New York, Oxford University Press.

Seibert, S.E., Kraimer, M.L. and Liden, R.C. (2001). "A Social Capital Theory of Career Success”. Academy of Management Journal, 44 “): 219-237.

Senge, P. (1990). The Fifth Discipline. Doubleday, New York. 
Slater, S. F. and Narver, J.C. (1995). "Market Orientation and the Learning Organization". Journal of Marketing, 59, July: 63-74.

Soo, C.W., Devinney, T.M. and Midgley, D.F. (2004). "The Role of Knowledge Quality in Firm Performance". In Tsoukas, H. and Mylonopoulus, N. (eds.), Organizations as Knowledge Systems. Knowledge, Learning and Dynamic Capabilities. Palgrave Macmillan.

Spender, J.-C. (1996). "Making Knowledge the Basis of a Dynamic Theory of the Firm". Strategic Management Journal, 17 (winter special issue): 45-62.

Stewart, T.A. (1997). Intellectual Capital. The New Wealth of Organizations. Currency Doubleday.

Teece, D.J., Pisano, G. and Shuen, A. ( 1997). "Dynamic Capabilities and Strategic Management”. Strategic Management Journal, 17 (Winter Special Issue): 509-533.

Tippins, M. J. and Sohi, R. S. (2003). "IT Com petency and Firm Performance: Is Organizational Learning a Missing Link?”. Strategic Management Journal, 24 (8): 745-761.

Vekstein, D. (1998). "Managing Knowledge a nd Corporate Perform ance: An Em pirical Analysis of the World Automobile Industry". Omega, 26 (5): 551-568.

Vera, D. and Crossan, M. (2003). "Organizational Learning and Knowledge Management: Toward an Integrative Fram ework". In M. Easterby-Smith and M. Lyles (eds.) (2003):

Handbook of Organizational Learning and Knowledge Management. Oxford: Blackwell: 123141.

Wiklund, J. and Sheperd, D. (2003). "Knowle dge-Based Resources, Entrepreneurial orientation, and the Perform ance of Small and Medium -Sized Businesses". Strategic Management Journal, 24: 1307-1314. 
NOTAS 